\title{
INSPETORIA DA INSTRUÇÃO PÚBLICA E PROFISSÃO DOCEN- TE NO MARANHÃO IMPÉRIO
}

\author{
INSPECTION OF PUBLIC INSTRUCTION AND TEACHING PROFESSION IN MA- \\ RANHÃO EMPIRE
}

\author{
INSPECTORIA DE LA INSTRUCCIÓN PÚBLICA Y LA PROFESIÓN DOCENTE EN \\ MARANHÃO IMPÉRIO
}

\author{
César Augusto Castro \\ Doutor em Educação. Professor Associado VI/ UFMA. São Luis, Maranhão, Brasil. \\ ccampin@terra.com.br
}

Samuel Luis Velázquez Castellanos Doutor em Educação. Professor Adjunto II/UFMA. São Luis, Maranhão, Brasil. samuel@ufma.br

Josivan Costa Coelho Historiador pela UFMA. Pesquisador do NEDHEL. josivancoelho@gmail.com

\begin{abstract}
RESUMO: Este trabalho centra-se na análise do papel da Inspetoria da Instrução Pública no Maranhão, principal órgão de regulação e controle do ensino nas escolas públicas e particulares, resgatando o processo de escolarização formulado pelos legisladores, focalizando as políticas públicas de controle e regulação sobre quem e o que era ensinado nas escolas. A partir do levantamento e análise da documentação oficial, formulada pelos funcionários provinciais foi possível identificar os diferentes níveis de instrução formal; as intencionalidades impostas na província; a percepção de uma educação primária baseada na carência de materiais da cultura escolar, os vencimentos que obrigavam os docentes a terem outras ocupações e a falta de espaços apropriados para as aulas, a grande maioria, funcionando na casa dos professores. Fica claro, ainda, a necessidade de se estabelecer novas modalidades de controle ou cerceamento à circulação de ideias que, porventura, questionassem os pilares da sociedade cristã/católica, motivando uma reformulação dos modelos censores para procederem com maior eficácia um patrulhamento ideológico sob alguns indivíduos.
\end{abstract}

PALAVRAS-CHAVE: Inspetoria Pública. Regulação do Ensino. Maranhão Imperial.

ABSTRACT: This paper focuses on analyzing the role of the Inspectorate of Public Instruction in Maranhão, the main organ for the regulation and control of education in public and private schools, bringing out the schooling process formulated by legislators, focusing on regulatory and control public policy about who and what was taught in schools. From the survey and analysis of official documentation, formulated by provincial officials, it was possible to identify different levels of formal education; the intentionalities that occurred in the province of Maranhão; the perception of a primary education based on lack of material of the school culture, the salaries that forced teachers to have other occupations and the lack of appropriate spaces for classes, the vast majority of teachers worked at home. It's clear the need to establish new forms of control or restriction to the flow of ideas, which, perhaps, questions the pillars of the Christian / Catholic society, prompting a redesign of the censors models to proceed more effectively with an ideological patrol about some individuals.

KEYWORDS: Public Inspection. Regulation of Education. Maranhão Imperial Age.

RESUMEN: Este trabajo se centra en el análisis del papel de la Inspectoría de la Instrucción Pública en Maranhão, principal órgano de regulación y control de la enseñanza en las escuelas públicas y particulares, rescatando el proceso de escolarización formulado por los legisladores, con foco en las políticas públicas de control y de la regulación sobre quién y sobre qué, se enseñaba en las escuelas. A partir del levantamiento y del análisis de la documentación oficial, formulada por los funcionarios provinciales, fue posible identificar los diferentes niveles de instrucción formal; las intencionalidades impuestas en la provincia; la percepción de una educación primaria basada en la carencia de materiales de la cultura escolar, los salarios que obligaban a los docentes a tener otras ocupaciones y la falta de espacios apropiados para las clases, la gran mayoría, funcionaba en la casa de los profesores. Queda evidente, aún, la necesidad de establecerse nuevas modalidades de control o de regulación a la circulación de ideas que, pudieran cuestionar los pilares de la sociedad cristiana/católica, motivando una reformulación de los modelos censores, para que procediesen con mayor eficacia, a un patrullamiento ideológico sobre algunos individuos.

PALABRAS CLAVE: Instrucción Pública. Regulación de la Educación. Maranhão Imperial.

Artigo recebido em janeiro de 2015

Aprovado em março de 2015

Cad. Pes., São Luís, v. 22, n. 1, jan./abr. 2015 
INSPETORIA DA INSTRUÇÃO | César Augusto Castro, Samuel Luis V. Castellanos e Josivan C. Coelho

\section{1 | INTRODUÇÃO}

A história da educação formal neste país tem sua gênese com a chegada da Ordem dos Padres Jesuítas, a qual mobilizou esforços no intuito da conversão dos nativos à Fé cristã e da imposição e obediência aos preceitos estabelecidos pelas Leis e pelo Rei de Portugal. Nessa fase da história da educação, os professores eram religiosos do sexo masculino, característica que predominou por quase todo o período imperial. Magistério primário que se institucionalizou no Brasil, como profissão masculina, em virtude da prerrogativa que este gênero tinha em relação às atividades intelectuais e públicas, segundo Melo (2011).

Nunes (2011) a este respeito corrobora esta realidade, ao afirmar que a profissão docente em seus primórdios foi exclusivamente masculina e religiosa, com o predomínio dos jesuítas. Situação de gênero que não se modifica mesmo depois das reformas pombalinas em Portugal e em suas colônias com a laicização do ensino, ao criar a categoria de professor régio. No entanto, embora as mudanças tenham ocorrido de forma lenta e gradual, a partir das medidas tomadas pelo Estado que passa a ser responsável pela disseminação da cultura letrada, atribuindo-lhe tal missão e responsabilidade aos professores leigos; na contramão, a subordinação dos docentes à autoridade do Estado permeou o estigma que perseguiu o professor: ser tratado como uma espécie de clérigo leigo, o controle excessivo de sua vida, ações e projeções, e a atuação pedagógica improvisada em espaços inadequados ou nas próprias residências (NUNES, 2011).

Outras transformações importantes ocorreram no período imperial, como a promulgação da Constituição de 1824 e da Lei de 1827 que institui a criação de escolas em todas as cidades, vilas e lugarejos mais populosos, com a atuação de mestres que garantiriam o ensino das quatro operações matemáticas, a leitura e a escrita, o catecismo e a economia doméstica. Essa lei marcaria a pretensa presença dos mestres nas escolas de primeiras letras, em todo o território nacional. Entretanto, é a partir do Ato Adicional de 12 de agosto de 1834, que começam a aparecer em todas as províncias dispositivos legisladores de toda ordem sobre a carreira do professor, referendando as licenças, os concursos, as aposentadorias, as gratificações, entre outros atos reguladores, ao mesmo tempo em que, a não-unidade implícita nessa primeira Lei orgânica do ensino, responsabiliza as Assembleias Provinciais de criarem e administrarem as escolas de primeiras letras e o ensino secundário, baseada na descentralização da instrução; isto é, caberia somente ao governo a responsabilidade de regularizar e administrar o ensino superior e às Provinciais, o poder de legislar sobre os outros níveis de ensino.

Entendemos que a instrução instituída por força do Ato Adicional (1834) foi um dos instrumentos utilizados pela classe dominante para servir a seus interesses. As propostas e realizações com vistas à constituição de um sistema de ensino provincial, sob o controle do estado que promovesse a difusão do ensino elementar à maior clientela possível, fundado numa ética cristã, foi sem dúvida uma tentativa de utilizar a instrução para perpetuar a ideologia dominante, para transmitir sua concepção de mundo e para preservar seus valores. Dito de outra forma, "as lutas de representações tem tanta importância como as lutas econômicas para compreender os mecanismos pelos quais um grupo se impõe, ou tenta impor, a sua concepção do mundo social, os valores que são os seus, e o seu domínio" (CHARTIER, 2002, p. 17).

No que tange à descentralização da instrução no contexto maranhense, Cabral (1984) aponta que as administrações manifestaram uma preocupação pela promoção, difusão e melhoria do ensino, ao denunciarem a situação deplorável em que se encontrava, e ao promover uma (re)organização que o modificara e o reinstituísse. Dessa forma, a primeira Lei orgânica do ensino brasileiro, iniciou uma nova fase na história da instrução pública local, ao abrir debates e discussões sobre a necessidade da oferta e da expansão da escolaridade em todo o cenário 
INSPETORIA DA INSTRUÇÃO | César Augusto Castro, Samuel Luis V. Castellanos e Josivan C. Coelho

regional. Nesse sentido concordamos com Faria Filho (2007), quando afirma que a diversidade e a forma desigual como se desenvolveu o processo de escolarização primária "[...] não devem nos levar a acreditar que a descentralização político-administrativa pelo Ato Adicional de 1834 acabou por impedir o desenvolvimento da instrução primária no Brasil imperial" (FARIA FILHO, 2007, p. 138).

Nesse sentido, com relação às primeiras letras, observamos que as propostas educacionais locais centravam-se em políticas (embora desarticuladas!) de promoção e difusão do ensino, no intuito de garantir a ordem social, e o desenvolvimento moral, intelectual e político das camadas populares. Para tanto, se propagava a urgência de estender-se a instrução elementar a todas as classes, incluindo os menos favorecidos, ainda que se restringisse a um tripé normativo: a educação moral (fundamentada nos rudimentos da fé cristã), os conhecimentos elementares (sustentados nas práticas de ler, escrever e contar) e, a formação profissional (sapateiros, carpinteiros, alfaiates) e outras que ajudassem a formar cidadãos probos e morigerados.

Para alcançar essas finalidades estratégias foram pensadas, regulamentos se oficializaram e instituições reguladoras foram criadas, entre elas: a Inspetoria da Instrução Pública1, a Delegacia Literária ${ }^{2}$, o Conselho da Instrução Pública ${ }^{3}$ e a Junta Médica ${ }^{4}$. Silva (2011) aponta como no magistério a atitude oficial do controle das condutas esteve presente e latente, uma vez que os professores considerados no ideário comum, os baluartes da formação de uma mocidade que se pretendia pia e ordeira, por outro lado, por viverem das letras, suas condutas, posturas e formas de ensino não eram totalmente confiáveis, já que poderiam abalar os valores e os pilares do antigo regime e da religião, si se posicionassem na contraordem; indícios que podem justificar a rígida formação cristã, o cumprimento dos ritos sacramentais e a severa cobrança dos conteúdos das sagradas escrituras nos exames. Dito de outra forma, aqueles que no trabalho cotidiano, os livros eram companheiros inseparáveis (considerados como bens que despertavam simultaneamente fascínio e temor), recebiam os olhares desconfiados de grande parte da sociedade, que se os admiravam pela dedicação às letras e ao intelecto, temia-os por serem mais suscetíveis a uma postura contraria e desestabilizadora (SILVA, 2011). Não obstante, mesmo que não nos seja possível aferir os níveis de instrução desses professores, o excessivo controle recaiu sobre eles pela natureza da profissão, pela proximidade à mocidade, e por terem (se quiserem!) como contaminá-la com os nocivos germes da desobediência à fé, à lei e à coroa.

Diante do exposto, nossa problemática se fundamenta em analisar em que medida a Inspetoria da Instrução Pública maranhense, com seus dispositivos reguladores e suas práticas punitivas repercutiram no magistério e nos fazeres pedagógicos dos professores e, por conseguinte, na gradativa promoção e institucionalização do ensino primário e secundário na província do Maranhão no período imperial? Nesse sentido, este texto objetiva demonstrar o papel da Inspetoria da Instrução Pública, como principal órgão de regulação e controle do ensino nas escolas públicas e particulares maranhenses (primárias e secundárias) no I e no II reinado, auxiliando-nos de quatro

\footnotetext{
${ }^{1}$ Criada pela Lei n. ${ }^{\circ} 115$, de $1 .^{\circ}$ de setembro de 1841.

${ }^{2}$ No segundo regulamento, de 1854 , elaborado de acordo com o $§ 2$ do artigo 15 da Lei n. ${ }^{\circ} 234$, de 20 de agosto de 1847, se autoriza à inspetoria a reorganizar o ensino elementar e secundário de toda a província e se cria o cargo de Delegado Literário.

${ }^{3}$ A Congregação do Liceu passa a denominar-se Conselho da Instrução Pública segundo o Art. 16 da Lei n. ${ }^{\circ} 267$, de 17 de dezembro de 1849, para resolver os problemas do ensino primário e era composta por professores do Liceu, dois professores primários do setor público sob a presidência do diretor.

${ }^{4}$ Criada em janeiro de 1854 (na documentação pesquisada não localizamos a Lei que a criou) e aparecem suas atribuições no Regulamento da Instrução Pública de 1854.
} 
INSPETORIA DA INSTRUÇÃO | César Augusto Castro, Samuel Luis V. Castellanos e Josivan C. Coelho

fases: 1) identificar os diferentes níveis de instrução formal, na tentativa de apreender as intencionalidades postas no processo de escolarização formulado pelos legisladores; 2) focalizar nas políticas educacionais, nos critérios de escolha dos professores e dos conteúdos selecionados/ permitidos nos espaços escolares no intuito de compreender a malha interposta entre a ação governamental, a profissão professor e a própria escola; 3) evidenciar a carência da cultura material escolar e o salário insipiente dos docentes que os obrigavam a ter ocupações paralelas ou abandonar o magistério; e 4) expor a carência de espaços apropriados no caso do ensino primário, o qual na maioria das vezes se caracterizava como uma educação doméstica. Instrução primária e secundária que foram pensadas e direcionadas para a coerção e o disciplinamento, a fim de enquadrar a mocidade nos parâmetros de civilidade, considerados aqui como o "fetiche do século XIX" (CARDOSO, 1977).

O Liceu Maranhense criado em 1838, com o intuito de formar a elite econômica local para ocupar os cargos públicos mais importantes, baseava sua formação em um ensino propedêutico para o ensino superior, e ainda concentrava no seu corpo docente figuras de grande vulto político e intelectual, entre eles: Sotero dos Reis e Felipe Conduru. Esses rastros documentados nos dão indícios das diferentes concepções de ensino e das distintas intencionalidades implícitas na instrução pública: uma educação primária coercitiva, visando normatizar o comportamento das classes desfavorecidas por meio dos ideais civilizatórios, ordeiros e higiênicos considerados parte do ensino popular, e uma instrução/educação elitizada, baseada na distinção e no requinte como formas de acesso aos mais altos postos administrativos de uma província onde a maioria da população era escrava e analfabeta.

Esta pesquisa vem ao encontro dos pressupostos estabelecidos pela Nova História, que possibilita ao historiador direcionar seu olhar não exclusivamente aos grandes fatos e eventos, e pela Nova História Política que enfatiza a análise e o entendimento de novos sujeitos e de novas fontes, rejeita uma visão holística da história e enfatiza o poder das instituições reguladoras. Dessa forma, ao alargar as perspectivas de análise e ao dar voz a sujeitos históricos esquecidos ou ocultados pela historiografia tradicional, se tentará reconstituir a partir das representações feitas pelos formuladores do discurso oficial, o cotidiano escolar maranhense, mais especificamente, das instituições que visavam normatizar a profissão docente com o intuito de moldar os comportamentos da clientela atendida, como é o caso das escolas públicas primárias. Essas instituições ou espaços escolares tiveram um caráter diferenciado no que tange aos conteúdos e às intencionalidades regulamentadoras, uma vez que o ensino instituído enfatiza mais os preceitos estabelecidos pelo Estado e pela Igreja, que pela própria disseminação da cultura letrada.

Para proceder à análise, localizamos documentos manuscritos e em avançado estado de deteriorização, que se encontram armazenados no Arquivo Público do Estado do Maranhão (APEM), principalmente, os ofícios e os relatórios dos inspetores da instrução pública que eram endereçados para os presidentes da província, e ainda, os regulamentos elaborados pelos presidentes e encaminhados à Assembleia Legislativa, cujo intuito era a uniformização do ensino público formal, estabelecendo regras a serem seguidas por todos os envolvidos no processo de disseminação dos conhecimentos e da moralização. Para Castro (2007) os documentos manuscritos e impressos armazenados em bibliotecas e arquivos contribuem para o resgate das memórias perdidas em papéis nem sempre conservados, trazendo fragmentos de informações corroídas pelo tempo, o que dificulta a montagem do corpus textual sobre o conjunto de práticas e saberes construídos por homens e mulheres do passado; no entanto nos alerta que o historiador não deve encarar o documento como monumento, quando afirma que: 
INSPETORIA DA INSTRUÇÃO | César Augusto Castro, Samuel Luis V. Castellanos e Josivan C. Coelho

\begin{abstract}
Os lugares de memória não são espaços de recolhimento da poeira, dos enunciados, mas é onde ocorre a ressurreição de uma multiplicidade de enunciados oferecidos ao tratamento e à manipulação. Esses enunciados trazem a marca de um tempo, de um lugar, das estratégias de agregação e apropriação de determinados valores, conceitos e formas de ajustamento, de trama de jogos de poder, de rituais e rupturas nos grupos sociais organizados. (CASTRO, 2007, p. 27).
\end{abstract}

Vários foram os percursos encarados para o procedimento da análise. Inicialmente, a transcrição da documentação existente no Arquivo Público referente à Instrução Pública foi necessária, especificamente, a leitura cuidadosa das correspondências enviadas por todos os atores envolvidos no cenário educacional, os ofícios dos professores públicos primários, que passavam pelas mãos dos delegados literários, pelos inspetores da instrução pública até chegar às mãos do presidente da província, além de relatórios elaborados pelos presidentes da província que eram endereçados à Assembleia Legislativa, fazendo-nos perceber a complexidade do sistema de monitoramento das práticas educativas.

O levantamento de tão avultado número de documentos nos fez perceber a estrutura das instituições educacionais maranhense no período, possibilitando elencar uma extensa lista de instituições e funcionários responsáveis pelo seu andamento. Dos regulamentos utilizados, damos destaque a dois regulamentos da Instrução Pública: um destinado para as escolas públicas primárias e o outro direcionado aos professores públicos, os quais foram elaborados na gestão do Presidente da Província Eduardo Olímpio Machado. O regulamento da Instrução Pública, de 2 de fevereiro de 1854, possivelmente, foi o primeiro do período imperial que pregava a reorganização do ensino elementar e secundário, trazendo em seus dispositivos aspectos referentes à inspeção escolar por meio da inspetoria da Instrução Pública, às condições de acesso ao magistério, aos direitos e deveres dos professores públicos e particulares, e os aspectos relativos ao ensino primário e secundário, público e particular. Já o Regulamento dos Professores da Província, tratava das interrupções autorizadas pelo governo para os docentes e das gratificações relacionadas ao número de alunos em suas aulas que por meio dos exames comprovassem o aprendizado da leitura, da escrita e do cálculo.

O Regulamento de 1874 trazia uma nova configuração organizacional. Ao contrário do legitimado em 1854 e do destinado aos professores (ambos formulados pelo Inspetor da Instrução), este foi elaborado pelo Conselho da Instrução Pública, órgão composto de cinco membros, nomeados pelo Presidente da Província dentre os lentes catedráticos do Liceu, sobre indicação do inspetor. O Regulamento de 1874, além de manter aspectos registrados no anterior, foi marcado pelo aumento no número de órgãos e de sujeitos, como o Conselho da Instrução Pública e os delegados Literários, que fiscalizariam a instrução, objetivando normatizar o comportamento dos indivíduos inseridos no contexto educacional maranhense. Por último, analisamos o Regulamento para as escolas públicas de primeiras letras formulados em 1877, pelo Conselho da Instrução Pública, onde eram estabelecidos aspectos relativos aos materiais que deveriam constar nas escolas, às obrigações dos professores e às proibições, às matrículas, às matérias do ensino, ao ano escolar, aos exames e à atuação dos delegados literários, entre outros aspectos.

Utilizamos como pressupostos teóricos, autores como Burke (2008), Chartier (2010), Hunt (2001) e Albuquerque Junior (2007) no intuito de compreender as novas perspectivas históricas abordadas pela Nova História, auxiliando-nos de Foucault (1987) e das categorias referentes às

\footnotetext{
${ }^{5}$ Os Regulamentos da Instrução Pública, de 1854 e de 1874. Regulamento dos professores da província, de 1854. Regulamento das escolas públicas de primeiras letras da província, de 1877.

${ }^{5}$ Publicado no dia 6 de julho de 1874.
} 
INSPETORIA DA INSTRUÇÃO | César Augusto Castro, Samuel Luis V. Castellanos e Josivan C. Coelho

instituições disciplinares. Com relação ao Maranhão nos subsidiaram Castellanos (2011, 2012), Castro (2007), Lacroix (1982), Serra Junior (2011) para entendermos os aspectos relacionados à escolarização formal no período em foco.

Nos itens que se seguem discorremos sobre o processo de disciplinarização do oficio docente, formulados pelos produtores do discurso oficial que tentavam incutir na sociedade imperial maranhense, especificamente, na população pobre livre (clientela do ensino público primário) os preceitos relativos à obediência das leis estatais e dos dogmas da religião oficial do estado. Acreditamos que a contribuição deste trabalho está no sentido de lançarmos um olhar sobre as intencionalidades da Instrução Pública Primária na província, trazendo a tona como o processo de escolarização formulado pelos legisladores perpassou por uma política pública de controle das populações pobres e livres, o que nos ampara a identificar, refletir e compreender o caráter político que a educação formal maranhense historicamente carregou, na obediência dos interesses das classes sociais dominantes; aspecto este que deve ser levado em conta quando nos referimos à História da Educação Maranhense.

\section{2 | AS AÇÕES FISCALIZADORAS DA INSTRUÇÃO PÚBLICA NA PROVÍNCIA DO MARA- NHÃO IMPERIAL}

Este item aborda a Inspetoria da Instrução Pública enquanto órgão fiscalizador do processo de instrução formal da província do Maranhão. O objetivo, nesta etapa é discutir aspectos relacionados aos dispositivos da inspeção, mostrando o quanto tais instituições estavam associadas à ideia de civilização e progresso, visando garantir a ordem e a hierarquia social vigente. Como característica marcante, o ensino público, transitava mais pelos valores morais e religiosos, no intuito de formar um homem virtuoso, do que pelo conhecimento intelectual. A partir desta perspectiva, vislumbrou-se qual tipo de ensino a província oferecia aos indivíduos que nela viviam.

No século XIX, o projeto de formação do Estado Nacional brasileiro, seguia atrelado ao entendimento da instrução pública como veículo possibilitador da hierarquização e da formação de indivíduos que constituiriam a nação. Segundo Marcilio (2006), a escolarização determinaria quem assumiria os principais cargos administrativos na Província, os cargos secundários (o funcionalismo público) e quem ficaria com os cargos de menor prestígio social. Para estes últimos, a instrução era necessária para o conhecimento dos deveres, em detrimento dos direitos, sob a égide hierárquica do indivíduo ou grupos de indivíduos no meio social.

Nessa temporalidade, o termo civilização estava relacionado ao comportamento urbano, à polidez nas atitudes, ao modo de vida, à construção de uma estrutura mental moderna e, acima de tudo, à tentativa de instituir o Estado. Esta organização, por parte dos governantes, significava manter a ordem e garantir as ideias impostas, estendendo o raio da autoridade sobre toda a Província. O progresso seria como o avanço da civilização, decorrente do desenvolvimento da indústria e, a instrução, a via pela qual os indivíduos compreenderiam a necessidade de um Estado (embora excludente!), que os representassem.

Os indivíduos teriam de ser preparados para a aquisição de novos hábitos fornecidos pela instrução, que disseminaria a ciência por meio dos preceitos da higiene e da estética. Modelo rumo ao progresso que deveria ser seguido pela elite e pela população, como demonstram os registros do Regulamento da Instrução Pública de 1874 , no art. $6^{\circ}$, o qual dispõe que:

O ensino primário é obrigatório. Os pais, tutores, curadores, protetores, que tiverem sob seu poder meninos maiores de 7 anos, sem impedimento físico e não lhes derem ensino primário, em casa, escola pública ou particular, incorrerão na multa de dez a trinta mil reis, que será repetida de seis em seis meses, se continuar a falta de cumprimento dessa obrigação. (MARANHÃO, 1874). 
INSPETORIA DA INSTRUÇÃO | César Augusto Castro, Samuel Luis V. Castellanos e Josivan C. Coelho

É possível evidenciar que a obrigatoriedade do ensino primário estava diretamente ligada ao ideal de civilização imposto pelas elites dirigentes, em oposição ao ensino secundário direcionado para a formação da burocracia estatal. Marcilio (2006) aponta que na província de Santa Catarina alunos do ensino secundário que tivessem a aprovação em todas as matérias teriam seu diploma assinado pelo Presidente da Província, pelo Inspetor da Instrução Pública e pelo Diretor do Ateneu. Este diploma conferia o direito de nomeação a qualquer emprego da Província (independentemente de concurso), e serviria como título de habilitação aos concursos públicos para o preenchimento das cadeiras de instrução primária e secundária. Deste modo, embora não oferecesse cadeiras destinadas à formação pedagógica ou técnica-administrativa, o curso secundário do Ateneu Catarinense habilitava seus alunos para o magistério e para compor os quadros da máquina administrativa.

Nesse contexto, não se podia continuar negando a escolarização aos segmentos desfavorecidos, principalmente porque era necessário fornecer uma base capaz de conferir alguma civilidade à população como um todo; apesar de que a elite insistisse na diferenciação dos conteúdos escolares, no intuito do controle dos sinais de revolta e de ambições, além de objetivarem por meio deles, ampliar as ideias de progresso, o que pode justificar a ampliação do ensino primário, e posteriormente, a sua obrigatoriedade. Entretanto, esta necessidade colidia com o perigo representado pelos indivíduos que detivessem o conhecimento intelectual, capazes de questionarem os fatos da realidade, o que representava uma constante ameaça à ordem social vigente. Deste modo, as formas de disciplinamento foram sendo metamorfoseadas, desde os tempos dos instrumentos de tortura até a atual "sociedade do espetáculo", transferindo-se o monitoramento físico para o ideológico, onde o controle de pensamentos, projeções e práticas foi legitimado, constante e cobrado.

Paralelamente, a disseminação gradativa das materialidades culturais desde no fim da idade média e inicio da moderna, da escolarização formal e de outras formas de absorção da cultura letrada, aumentaram significativamente a quantidade de leitores em potencial, expandindo-se numa velocidade até então desconhecida (SILVA, 2011). Nesse sentido, a necessidade de se estabelecer novas modalidades de controle ou cerceamento à circulação de ideias que, porventura questionassem os pilares da sociedade cristã/católica, motivando uma reformulação dos modelos censores para procederem com maior eficácia ao patrulhamento ideológico sob alguns indivíduos, era imponderável e necessária.

É nessa perspectiva que os professores públicos primários foram enquadrados já que o futuro da nação estaria a seus encargos. Sujeitos que apesar da parca instrução, deveriam ser controlados, na medida em que o fazer pedagógico se devia limitar a disseminar a obediência aos dogmas e às Leis estabelecidos pela Igreja/Estado. É neste contexto que se faz necessário criar instituições (sob a ótica do legislador) cujo intuito era regular o bom andamento da instrução, fazer o controle da profissão e das práticas de ensino, podendo-se afirmar que os professores públicos primários tornaram-se os principais alvos. Se para Marcilio (2006) a dificuldade de se encontrar pessoas aptas para a ocupação do cargo de professor poderia ser atribuída à baixa remuneração, carência que trouxe consequências nefastas, pois a insuficiência de mestres converteria muitas escolas em um só estabelecimento; para Castellanos (2010, 2011, 2012), a não existência de instituição formadora de professor até o advento da República, restringia os critérios de seleção para o magistério, ao conhecimento das operações básicas e à garantia dos bons comportamentos ${ }^{8}$.

\footnotetext{
${ }^{7}$ Expressão de Guy Debord (1997).

${ }^{8}$ A primeira iniciativa governamental de criação da Escola Normal para formar professores no Maranhão na primeira metade do século XIX foi liderada pelo seu diretor Felipe Condurú por meio do ensino mútuo ou método lancastrino. A segunda tentativa de se estabelecer uma Escola Normal na Província foi em 1874, pela iniciativa privada da Associação Onze de Agosto. A terceira tentativa só se concretiza de 1889, com o advento da Primeira República, mantida pelo tesouro provincial e funcionando como instituição durante 24 anos aproximadamente, denominando-se de Curso Profissional, anexo ao Liceu, em 1914 (CASTELLANOS, 2010, 2011, 2012).
} 
No Regulamento da Instrução Pública de 1874 se registra que só poderiam "[...] ser professores públicos os cidadãos brasileiros, que reunirem as condições seguintes: $1^{\circ}$. Idade maior de vinte anos; $2^{\circ}$. Moralidade; e $3^{\circ}$. Instrução profissional" (MARANHÃO, 1874). Para provar a instrução profissional, os candidatos deveriam se submeter aos exames de habilitação feitos publicamente perante o inspetor e três examinadores designados por ele, como registra o ofício enviado em 23 de janeiro de 1865, pelo Inspetor da Instrução Pública, Antônio Marques Rodrigues, para o Presidente da Província, Ambrosio Leitão Cunha, comunicando-Ihe acerca de um exame realizado, para admissão do cargo de professora da vila de Pinheiro:

Aos vinte dias do mês de janeiro do ano de mil oitocentos e sessenta e cinco, na sala
dos exames do liceu do Maranhão, achando-se presente o inspetor da instrução pública
o doutor Antônio Marques Rodrigues, e os examinadores os senhores Filippe Benicio de
Oliveira Condurú, professor público de primeiras letras da $3^{\circ}$ freguesia da capital, Alexan-
dre Jose Rodrigues professor jubilado da $2^{\circ}$ freguesia da capital e D. Antonia Senhorinha
Carneiro Belford Rego, professora do recolhimento, para o fim de proceder-se o exame
das opositoras á cadeira de primeiras letras do sexo feminino da vila de Santo lgnácio do
Pinheiro, e sendo presente somente a opositora D. Filomena Bandeira Pinto de Almeida,
foi esta examinada em todas as matérias do art. 27 parte primeira do regulamento de 2 de
fevereiro de 1855 , e aprovada plenamente em todas essas matérias. (MARANHÃO, 1865).

Tais procedimentos de seleção, para o acesso ao ofício docente por meio dos exames são facilmente identificados nas atas de exames elaboradas pelo secretário da Instrução Pública, que eram enviadas pelo Inspetor, para o Presidente da Província. Neste caso específico, evidenciasse a presença de uma mulher como examinadora, em tempos de escolas separadas por sexos, a qual seria responsável pelo julgamento dos trabalhos de bordado e agulha, como determinava o regulamento de 1874:

Nas escolas do sexo feminino além das matérias gerais, se ensinarão bordados e trabalhos de agulhas, estabelecendo ainda que quando o concurso for para provimento de cadeira do sexo feminino, um dos examinadores [seria] uma professora pública, que será especialmente ouvida sobre trabalhos de agulha. (MARANHÃO, 1874).

No entanto, apesar dos professores serem selecionados por possuírem alguns conhecimentos específicos e, acima de tudo, por terem um comportamento compatível com as exigências da época, não propagando ideias contrárias ao governo, concebendo o magistério como dever e tendo plenas convicções dessa missão; por sua vez, a moralidade era atestada pelos párocos dos lugares onde o candidato ao cargo residia, como demostra o oficio enviado em 31 de maio de 1864, pelo Inspetor da Instrução Pública, Jose da Silva Maya, ao Vice-Presidente da Província, Miguel Joaquim Ayres do Nascimento, no qual comunicava que:

Luiz Antonio Rodrigues, que requer ser admitido ao concurso aberto da cadeira de primeiras letras da vila do Cururupú, tenho a informar que o suplicante instrui a sua petição com documentos que provam a sua maioridade legal, a sua moralidade por folha corrida, e atestado do respectivo pároco, tanto que já foi examinado e aprovado em 28 de março do ano passado com opositor a cadeira de primeiras letras do Riachão, e por isso o entendo que a petição do mesmo esta no caso de ser favoravelmente deferida. (MARANHÃO, 1864, grifo nosso).

Em outras palavras, era necessário para ter acesso ao exame de admissão ao magistério público primário, comprovar a tríade reguladora: idade, moralidade e capacidade profissional, comprovada nos exames públicos. Para garantir que os indivíduos estivessem enquadrados para o 
exercício, a inspetoria tinha a função de controlar a postura dos professores, no momento da seleção, por meio de punições permitidas pela legislação ou ainda pela premiação aos que demonstrassem boa conduta. Tavares (2009) corrobora que para o controle das ações em torno da escolarização primária, foi necessária a criação de cargos públicos para o acompanhamento e a fiscalização das atividades desenvolvidas nas escolas públicas. Logo na década de 1850 e 1860, temos a presença do Inspetor público, responsável por gerenciar todo o ensino na província maranhense e os delegados literários, que auxiliavam ao inspetor no acompanhamento e na fiscalização das escolas, na capital e em outras localidades da província, que pela complexidade imposta pela abertura de mais escolas, se modificaram as estruturas e aumentara o quantitativo de servidores públicos.

\section{3 | A INSPETORIA DA INSTRUÇÃO PÚBLICA}

A Inspetoria da Instrução Pública foi criada pela Lei n. ${ }^{\circ} 115$, de $1 .^{\circ}$ de setembro de 1841 e tinha como principal objetivo manter o controle da educação escolar da província, estabelecendo aos professores como deveriam desempenhar suas funções. O legislador tinha uma preocupação maior na regulação do ensino primário por dois motivos: os professores serem responsáveis pela difusão dos ideais de civilidade impostos e pelo fato da clientela do ensino primário ser essencialmente pessoas livres e pobres. A presença de pessoas pobres como principal público alvo do ensino público primário é evidenciada nos documentos que foram analisados, nos quais aparecem listas de materiais pedidos para a aula de primeiras letras, como por exemplo, no ofício enviado em 19 de novembro de 1864, pelo Inspetor da Instrução Pública, Antônio Marques Rodrigues, para o Presidente da Província Ambrosio Leitão da Cunha, que solicita para a cidade de Caxias, além de outros objetos, "alguns compêndios de leitura, aritmética, geografia e catecismos para serem distribuídos pelos alunos pobres, e assim também papel, lápis, canetas, caixas de penas, e 12 lousas pequenas com os lápis" (MARANHÃO, 1864, grifo nosso). Por outro lado, o regulamento da Instrução Pública de 1874 também aponta que o Governo cederia os instrumentos indispensáveis para a manutenção de alunos pobres nas aulas públicas primárias da província e, ainda, asseguravam a entrada em escolas particulares, quando não existissem escolas públicas primárias disponíveis.

\footnotetext{
Quando em uma paróquia, por sua pequena população, falta recursos, ou qualquer outra circunstância, não se reunir número suficiente de alunos, que justifique a criação da escola particular bem conceituada, poderá o Presidente da Província, mediante uma gratificação razoável, e ouvido o inspetor da instrução pública, contratar com o professor dessa escola a admissão de alunos pobres. (MARANHÃO, 1874).
}

Como temos demostrado, os mecanismos de atuação da inspetoria da Instrução Pública se estendem desde o ensino particular, na liberação de licença para a atuação no magistério, até a abertura de escolas e a adoção de compêndios, onde se conclui que esta instituição teve jurisdição para inspecionar todos os ambientes de ensino e todas as pessoas envolvidas na disseminação do conhecimento formal, no intuito de prevenir possíveis desvios de conduta dos docentes, que influenciariam (em tese) diretamente na moralidade dos alunos e ameaçariam o plano de civilidade/obediência colocado em prática. No entanto, em contraposição a esse ensino, cujo intuito era a disciplinarização de professores e alunos, o ensino secundário maranhense ocupou lugar de destaque nos regulamentos no que tange ao número elevado de disciplinas, como dispunha o Regulamento da Instrução Pública de 1854: 
INSPETORIA DA INSTRUÇÃO | César Augusto Castro, Samuel Luis V. Castellanos e Josivan C. Coelho

\begin{abstract}
Latim, em duas aulas primária e superior; Inglês, Francês, Geografia, principalmente geografia do Brasil, História antiga, media, moderna, principalmente historia do Brasil, Filosofia racional e moral, Retórica e poética, Matemática elementar, Cálculo mercantil, Desenho Linear e tipográfico, Gramática geral. (MARANHÃO, 1854).
\end{abstract}

Os Lentes do Liceu Maranhense ocuparam lugar de destaque na época e, posteriormente, tornaram-se figuras emblemáticas no campo da literatura e da política, destacando-se dentre outros, Sotero dos Reis, Felipe Condurú e Ricardo Jauffret. Francisco Sotero dos Reis (professor de latim) ocupou vários cargos dentro da administração pública, sendo o primeiro Inspetor da Instrução Pública e o primeiro diretor desta instituição, na qual o ensino secundário se caracterizou como preparatório e propedêutico: para que filhos das elites ocupassem os cargos administrativos da província e para a entrada no ensino superior das universidades europeias e das faculdades de direito e medicina esparsas pelo Brasil.

No que tange à inspetoria da instrução como instituição que visava o controle do ofício docente e no meio da constituição de uma nação civilizada, sua ação se fundamentava em que a instrução desse conta de legitimar a história escrita pela elite, possibilitando o conhecimento das leis e seu cumprimento, a divulgação de certo conhecimento da leitura e da escrita, e a garantia de um comportamento adequado, ordeiro e civilizado. Por outro lado, era responsabilidade da inspetoria a elaboração de mapas estatísticos, enviados posteriormente ao Presidente, os quais deveriam conter o número de escolas públicas e particulares, o quantitativo de alunos e de professores, o registro de frequências e faltas, a avaliação da aprendizagem no inicio e no final do curso, além dos nomes dos pais, dentre outras observações que detalhavam as condições do ensino. É nesse sentido que para Tavares (2009) este era o cargo central na instrução, uma vez que o inspetor era o gestor maior que direcionava todas as ações e presidia o Conselho Superior da Instrução Pública, o qual tinha um representante do Liceu e outro da Escola Normal (eleitos pela Congregação destes estabelecimentos) e um representante do professor primário da capital, que deveria ser eleito pela congregação dos professores primários das escolas subvencionadas pelo governo.

Embora criada em 1841, foi a partir de 1844, quando os ânimos ficam apaziguados depois da revolta da Balaiada, que a província do Maranhão conta com a ação de um órgão responsável pela fiscalização das escolas para legitimar as regras estabelecidas e garantir seu cumprimento. Cabia ao inspetor, juntamente com os delegados, a fiscalização e inspeção de todas as escolas públicas e particulares da província, no que se refere à regulação e à direção do sistema e do método prático do ensino. Entres as obrigações de dita instituição poderíamos citar: selecionar e organizar os livros didáticos e os utensílios para as escolas, no intuito de uniformizar os métodos de ensino e o material da cultura escolar; legitimar os regulamentos internos dos espaços escolares; orientar os professores sobre o desempenho de suas obrigações; observar os procedimentos utilizados pelos professores particulares; intermediar as negociações entre os professores e o governo, levando as solicitações, sugerindo representações, redigindo requerimentos e discutindo as exigências da classe docente, por meio da elaboração semestral de relatórios sobre o estado da Instrução Pública da Província; canal de mão dupla pelo qual professores, inspetoria e presidência da província pensavam, discutiam, denunciavam e negociavam as trilhas a serem tomadas na instrução da região.

Era comum que os inspetores tivessem outros cargos para que pudessem se manter e, com isso, ausentavam-se constantemente de seus fazeres, com a autorização dos presidentes da província. No Maranhão é avultado o número de indivíduos que ocupavam mutuamente as funções de fiscalização do ensino público formal e outras ocupações, podendo-se destacar a ocupação de cargos políticos. Ao mesmo tempo em que a instantaneidade cinematográfica ${ }^{9}$ dos governos no

Cad. Pes., São Luís, v. 22, n. 1, jan./abr. 2015 
Maranhão do I e II Reinado, e a não continuidade ou má administração no curral governamental (MEIRELES, 2001) sustentada pelas lutas do dualismo partidário entre conservadores e liberais, trouxeram consigo o não cumprimento de reformas ao longo prazo, seja no cenário social, seja no educacional. Presidentes de expedientes, que não podiam (pela dinamicidade na constante mudança administrativa das suas funções) planejar reformas que visassem o melhoramento do bem público e, muito menos executá-las.

No ofício de 3 maio de 1854, o inspetor, Caetano José de Sousa comunica, ao presidente, Eduardo Olímpio Machado que

Tendo sido convidado para tomar assento na assembleia legislativa provincial na qualidade de deputado suplente e não podendo por este motivo continuar a exercer as funções de inspetor da instrução publica assim comunico a V. Ex a fim de dignar se nomear um substituto para exercer este cargo, durante o meu impedimento na câmara provincial. (MARANHÃO, 1854).

Contudo, mesmo com as mudanças no setor governamental, na documentação se responsabilizam os professores pelo fracasso da instrução pública, destacando-se a necessidade de maior fiscalização, como evidencia Caetano Jose da Silva, em ofício enviado, para o presidente, em 1855, no qual registra que "o que importa não é ter a instrucção cadeiras ou aulas públicas, e pagar professores, mas que estes ensinem como devem. A grande difficuldade neste assumpto é ter professores capazes, zelosos" (MARANHÃO, 1855); concepções que estimulam a aplicação de penas aos mestres por meio dos dispositivos legais, a exemplo do Regulamento da Instrução Pública de 1854, no qual se determinava que:

As penas serão impostas pelo inspetor da instrução pública; as duas primeiras, sem recurso; a última com o recurso para o Presidente da Província, interposto, porém, dentro do prazo de 50 dias contados da intimação. O mesmo inspetor representara ao Presidente da Província para suspender administrativamente o professor e mandá-lo responsabilizar: Quando o professor se não corrigir sua negligencia com a imposição das penas disciplinares; Quando desobedecer ou faltar ao respeito em ato de serviço a ele inspetor e mais pessoas incumbidas da inspeção do ensino; Quando sem ser em tempo de férias, abandonar a sua cadeira sem licença ou exceder a licença por motivo não justificado; Quando der maus exemplos na aula e fomentar a imoralidade entre os alunos. (MARANHÃO, 1854).

Se a necessidade de controle dos professores públicos era a pauta do dia, e se os mecanismos de fiscalização tutelavam suas práticas, na medida em que "só a vigilância e a fiscalização constante [poderiam] conter os professores no cumprimento dos seus deveres. [Já que] o professorado exige dedicação, e a fiscalização do ensino demanda grande severidade e energia de caráter" (MARANHÃO, 1857) ${ }^{10}$; no entanto, em outra direção, Batista (2005) comenta como a falta de casas adequadas para o bom funcionamento das escolas, a falta de móveis e de acessórios (pedra de lousa, lápis de escrita, tinta, tinteiro, papel, pena, cartilhas, tabuadas, etc..), além do pouco número de escolas, foram fatores decisivos para a deficiência do ensino, segundo os comunicados da inspeção provincial. Aspectos que podem ser demostrados nos argumento extraídos do relatório enviado em 11 de abril de 1855, por Caetano Jose da Silva, inspetor da Instrução Pública, ao Presidente da Província, Olimpio Machado:

\footnotetext{
${ }^{9}$ Conceito trabalhado por Fran Paxeco na sua obra Geografia do Maranhão, em 1923.

${ }^{10}$ Relatório do Presidente da Província Benvenuto Augusto de Magalhães Taques, em 1857.
} 
INSPETORIA DA INSTRUÇÃO | César Augusto Castro, Samuel Luis V. Castellanos e Josivan C. Coelho

\begin{abstract}
O professor Alexandre Jose Rodrigues dá aula em um corredor da igreja de São João no lado que olha para o sul. Este corredor não só não tem capacidade para admitir o numero de alunos que regularmente freqüenta essa escola como é escuro, extremamente quente e não tem lugar algum para satisfação das necessidades corporais. O professor Sebastião Pedro Nolasco dá aula em uma sala térrea do prédio em que funciona o tribunal da relação, que alem das mesmas inconvenientes da outra escola oferece mais um, que é não poderem as lições nos dias de trabalho daquele tribunal durar ate a hora prescrita pelo respectivo regulamento. (MARANHÃO, 1855).
\end{abstract}

Averiguar o modo como os professores difundiam os conhecimentos referentes à Instrução Pública, seus comportamentos, atitudes e crenças não foram suficientes por parte da inspeção governamental. A identificação e a avaliação de possíveis atitudes oficiosas dos próprios delegados literários, por prováveis atitudes permissivas com respeito aos professores (por estarem longe da capital), podem ser encontradas na proposta de criação de agentes extraordinários da própria inspeção, como sugere o Presidente da Província, em 1855:

O inspetor da instrucção pública propõe a creação de agentes extraordinários da inspeção, ou visitadores das escholas, nomeados em epochas incertas, com vantagens sufficientes, os quaes, percorrendo o interior da província, inspecionem as escholas, inquiram do proceder dos professores, verifiquem a sua capacidade e dedicação ao ensino, e de tudo dêem indormações exacta. (MARANHÃO, 1855).

Estas visitas não programadas insinuam certa desconfiança não só com o professorado, como também com os próprios delegados literários, os quais por serem funcionários responsáveis pela fiscalização ordinária das aulas públicas no interior da província, e estarem longe do centro da fiscalização (situado na capital) poderiam faltar com suas atribuições e encargos. Proposta governamental que parece recomendar que as visitas extraordinárias, levassem os olhos da cidade ao interior, evitando assim desvios de condutas de qualquer natureza nos indivíduos inseridos no cenário da instrução.

Na contramão deste leque de atitudes, medidas e punições direcionadas aos sujeitos atuantes no magistério, outras estratégias são tomadas para estimular a permanência na docência, concedendo-se prêmios como recompensa aos que se tornavam notáveis, a exemplo das composições de livros didáticos para uso das escolas e, da tradução das melhores produções, sendo publicadas em línguas estrangeiras. Gratificações extraordinárias foram também concedidas àqueles que tivessem lecionando por mais de 20 anos no serviço efetivo, sendo descontados os pedidos de licença (VIVEIROS, 1936); embora possamos questionar a efetividade desta gratificação, uma vez que o período para o recebimento é bastante próximo ao tempo necessário para a aposentadoria dos professores públicos. Tal fato é constatado pelo Regulamento da Instrução Pública de 1854, no qual o Presidente da Província, com o intuito de reorganizar o ensino primário e secundário, ordena no Art.13 a 16 que:

O professor, que contar 25 anos de serviço efetivo, poderá sair jubilado com o ordenado por inteiro. Aquele que, deste prazo, ficar impossibilitado de continuar a servir, poderá ser jubilado com a parte do ordenado proporcional ao tempo, que tiver efetivamente servido, não podendo, porem, gozar deste favor antes de haver exercido o magistério por 10 anos. Os jubilados, que forem pelo motivo da segunda parte do artigo antecedente, não poderão exercer emprego algum de nomeação do governo. O professor terá direito ao aumento da quarta parte do seu ordenado, quanto o governo julgar conveniente conservá-lo no magistério depois de 25 anos de efetivo serviço. A jubilação, quando não for decretada pelo governo sobre proposta do inspetor da instrução pública, poderá ser requerida pelo professor. (MARANHÃO, 1854).

Cad. Pes., São Luís, v. 22, n. 1, jan./abr. 2015 
INSPETORIA DA INSTRUÇÃO | César Augusto Castro, Samuel Luis V. Castellanos e Josivan C. Coelho

No mesmo regulamento, no que diz respeito às práticas punitivas sobre os professores, se destaca que aquele que, no decurso do ano letivo, tivesse faltado vinte vezes sem causa justificada (a juízo da congregação com exclusão do membro sobre o qual versa a questão) deveria ser descontada a quinta parte do ordenado, logo no $1^{\circ}$ quartel do ano seguinte; por outro lado, aquele que por negligência não cumprisse seus deveres de instruir os alunos, deixando de dar aula sem justificar por mais de três dias em um mês, e infligisse nas disposições dos respectivos regulamentos, ficaria sujeito às seguintes penas disciplinares: admoestação, repreensão e multa de $10 \$ 000$ a $30 \$ 000$ reis. Enfim, a função do Inspetor da Instrução Pública estava no topo de uma hierarquia de vigilância da Instrução Pública e, mais especificamente, do oficio docente, na medida em que, para que tal rede de controle/punição se tornasse mais efetiva foram criadas outras instituições e, consequentemente, outras funções que possibilitaram um controle mais próximo, no intuito de eliminar as probabilidades de burlar as ações do órgão central.

\section{4 | CONSIDERAÇÕES FINAIS}

A análise dos documentos oficiais, formulados pelos ocupantes dos cargos relativos à instrução pública, nos subsidiaram na percepção de uma complexa rede de vigilância ao ensino público e particular maranhense no Oitocentos, com ênfase ao ensino elementar. O Regulamento de 1874 além de conter aspectos já legitimados no regulamento de 1854 é marcado pelo aumento no número de órgãos e sujeitos cujo objetivo era fiscalizar, vigiar e punir por meio do Conselho da Instrução Pública e dos Delegados Literários, para garantir a normatização dos comportamentos de indivíduos inseridos no contexto instrucional.

No que diz respeito ao exame das correspondências, foi possível comparar segundo os registros estabelecidos nos regulamentos, o embate "ideal" e "real" entre a imposição e a resistência, apontando-nos fatos relacionados à vigilância por parte das instituições responsáveis pela ordem da instrução formal, evidenciadas por meio das negações de licenças, das aposentadorias e dos indeferimentos de petições relacionadas a inúmeros aspectos. No entanto, essa documentação nos permitiu também trazer à tona aspectos em que a "letra dura" dos regulamentos não possibilita captar, as formas de resistências, em que os professores públicos primários tentam burlar a ação das instituições reguladoras da Instrução Pública.

Quando nos questionamos sobre as formas de controle e de poder que os órgãos exerciam sobre os professores, evidenciamos que as ações estavam relacionadas à vigilância dos conteúdos e dos comportamentos, na medida em que a moralidade atestada pelo pároco do local onde residia o professor candidato ao magistério, a certidão de idade comprovada pela certidão de batismo, e a capacidade profissional avaliada no concurso público, seriam pré-requisitos que o condicionariam à candidatura, e não obrigatoriamente a sua efetividade, já que outros aspectos estavam em questão. Por outro lado, a Inspetoria da Instrução Pública, como evidenciamos, foi o órgão central de inspeção na província maranhense, tendo a responsabilidade de delinear os rumos a serem tomados pelo ensino público e particular na Província, além de avaliar os pedidos de licença, a nomeação de cargos, dos examinadores de concursos, dos delegados literários e seus respectivos suplentes, dos membros do conselho da instrução, dentre outras atribuições estabelecidas pelos regulamentos.

Os apontamentos que podemos fazer acerca dessa complexa hierarquização das funções corroboram para o sentido de que a instrução formal para além de uma organização, cuja intencionalidade era o bom andamento da instrução, perpassava por uma questão de cunho político, obedecendo à tendência cuja reprodutibilidade das desigualdades econômicas foram repassadas e legitimadas por meio do campo educacional. A educação formal, mais especificamente, a ele- 
INSPETORIA DA INSTRUÇÃO | César Augusto Castro, Samuel Luis V. Castellanos e Josivan C. Coelho

mentar, tinha por objetivo a formação de um corpo de indivíduos no qual o interesse dos governantes era capacitar mão de obra para as atividades manuais, e de pessoas que não se insurgissem contra o poder imperial. Tais ações focalizaram o professor como figura central, por estar mais próximo aos futuros componentes do corpo social; daí a necessidade de terem seu oficio vigiado desde o momento do acesso, perpassando todas as etapas da instrução: o controle dos horários, dos conteúdos, da cultura material em uso, dos corpos, das relações, das vestimentas, da vida pessoal, de todo o referente aos comportamentos dentro e fora do ambiente escolar.

Por fim, esperamos que este estudo possibilite uma maior compreensão acerca da Instrução Pública Primária da Província do Maranhão no Oitocentos, contribua com os historiadores que pesquisem assunto atinentes ao tema em questão, e possa estimular uma constante revisão e aprofundamento da História da Educação Maranhense num processo continuo de construção e reconstrução que sugira novos objetos, novas fontes, novas metodologias e novas projeções; isto é, pesquisar a instrução maranhense partindo da "[...] maneira como nas práticas, nas representações ou nas produções, se cruzam e imbricam diferentes formas culturais [e sociais]" (CHARTIER, 1988, p. 56). 
INSPETORIA DA INSTRUÇÃO | César Augusto Castro, Samuel Luis V. Castellanos e Josivan C. Coelho

\section{Referências}

ALBUQUERQUE JUNIOR, D. M. de. História: a arte de inventar o passado: ensaios de teoria da história. Bauru, SP: EDUSC, 2007.

BATISTA, L. T. A. Educação e elite na São Luís da segunda metade do século do XIX. 2005. Monografia (Graduação em História)- Universidade Estadual do Maranhão, São Luís, 2005.

BURKE, P. O que é história cultural? Tradução Sergio Goes de Paula. 2. ed. Rio de Janeiro: Jorge Zahar, 2008.

CABRAL, M. do S. C. Política e educação no Maranhão (1834-1889). São Luis: SIOGE, 1984.

CARDOSO, F. H. Capitalismo e escravidão no Brasil meridional: o negro a sociedade escravocrata do Rio Grande do Sul. São Paulo: Difusão, 1977.

CASTELLANOS, S. L. V. O livro escolar no Maranhão Império: produção, circulação e prescrições. 2012. 468 f. Tese (Doutorado em Educação Escolar)- Universidade Estadual Paulista Júlio de Mesquita Filho, Araraquara, 2012.

Práticas leitoras no Maranhão na Primeira República: entre apropriações e representações. São Luís: EDUFMA, 2010.

Sociedade Onze de Agosto: uma instituição de ensino popular no Maranhão Império (1870 - 1876). In: MADEIRA, A. C. F.; MADEIRA, M. das G. de L. (Org.). Instituições escolares e escolarização no nordeste. São Luís: EDUFMA; UFBP; Café \& Lápis, 2011.

CASTRO, C. A. Infância e trabalho no Maranhão Provincial: uma história da Casa dos Educandos Artífices (1841-1899). São Luis: EDFUNC, 2007.

CHARTIER, R. A história ou a leitura do tempo. Tradução Cristina Antunes. 2. ed. Belo Horizonte: Autêntica, 2010.

História cultural: entre práticas e representações. Rio de Janeiro: Bertrand-Brasil, 1988.

$\overline{2002 .}$ Os desafios da escrita. São Paulo: UNESP,

DEBORD, G. A sociedade do espetáculo. Rio de Janeiro: Contraponto, 1997.

FARIA FILHO, L. M. Instrução elementar no século XIX. In: LOPES, E. M. T.; FARIA FILHO, L. M.; VEIGA, C. G. 500 anos de educação no Brasil. 3. ed. Belo Horizonte: Autêntica, 2007.

FOUCAULT, M. Vigiar e punir. Petrópolis: Vozes, 1987.
HUNT, L. A nova história cultural. Tradução Jefferson Luiz Camargo. São Paulo: Martins Fontes, 2001.

LACROIX, M. de L. L. A educação na Baixada Maranhense (1822-1889). São Luis: SECMA, 1982.

MARANHÃO. Instrução Pública. Ofícios de Antonio Marques Rodrigues. APBEM. cx. 2. 1865.

. Instrução Pública. Ofícios de José da Silva Maia. APBEM. cx. 1. 1864.

Regulamento Geral da Instrução. 1854.

Regulamento da Instrução Pública. 1874.

Relatório do presidente da Província do

Maranhão, o doutor Eduardo Olympio Machado, na abertura da Assembleia Legislativa Provincial no dia 3 de maio de 1855, acompanhado do orçamento da receita e da despesa para o ano de 1856 e mais documentos. Maranhão: Tipografia Constitucional de I. J. Ferreira, 1855.

Relatório que a Assembleia Legislativa provincial do Maranhão apresentou na sessão ordinária de 1857 ao Presidente da Província Dr. Benvenuto Augusto de Magalhães Taques. Maranhão: Tipografia da Temperança, 1857.

MARCILIO. E. C. A ação da Inspetoria Geral da Instrução Pública na província de Santa Catarina no período de 1874-1888: a precariedade da inspeção escolar como instrumento para uniformização do ensino. 2006. Dissertação (Mestrado em Educação)- Universidade Federal de Santa Catarina, Florianópolis, 2006.

MEIRELES, M. M. História do Maranhão. 3. ed. São Paulo: Siciliana, 2001.

MELO, C. N. de. Docência feminina em escolas mistas: refazendo tempo, espaços e saberes na escola imperial paraense. In: LOPES, A. de P. C.; STAMATTO, M. I. S. (Org.). O oficio docente no norte Nordeste. São Luis: EDUFMA; UFPB; Café \& Lápis, 2011. p. 39-64. (Coleção tempos, memórias e história da educação, v. 3).

NUNES, I. de M. L. Profissão docente: marcos de um percurso. In: LOPES, A. de P. C.; STAMATTO, M. I. S. (Org.). O oficio docente no norte Nordeste. São Luis: EDUFMA; UFPB; Café \& Lápis, 2011. p. 65-82. (Coleção tempos, memórias e história da educação, v. $3)$.

PAXECO, F. Geografia do Maranhão. São Luis: Tipogravura Teixeira, 1923. 
INSPETORIA DA INSTRUÇÃO | César Augusto Castro, Samuel Luis V. Castellanos e Josivan C. Coelho

SERRA JUNIOR, A. S. Em defesa do Estado e da ordem pública: representações, controle e civilização dos pobres livres nos relatos dos presidentes da Província do Maranhão. 2011. Monografia (Graduação em História)Universidade Federal do Maranhão, São Luís, 2011.

SILVA, D. R. da. A institucionalização dos grupos escolares no Maranhão (1903-1920). Dissertação (Mestrado em Educação)- Universidade Federal do Maranhão, São Luís, 2011.
TAVARES, R. S. A infância no Maranhão Imperial: a escolarização pública primária da criança pobre e livre no período de 1855-1889. 2009. Dissertação (Mestrado em Educação)- Universidade Federal do Maranhão, São Luís, 2009.

VIVEIROS, J. de. Apontamentos para a história da instrução pública e particular do Maranhão: 1629 a 1889 (1. a parte). [S.I.: s.n.], 1936. 152 p. Mimeografado. 